\title{
Auditor's Ethical Judgments: The Influence of Moral Intensity, Ethical Orientation and Client Importance
}

\author{
Razana Juhaida Johari ${ }^{1}$, Zuraidah Mohd Sanusi ${ }^{2} \&$ Arumega Zarefar $^{3}$ \\ ${ }^{1}$ Faculty of Accountancy, Universiti Teknologi MARA, Selangor, Malaysia \\ ${ }^{2}$ Accounting Research Institute, Selangor, Malaysia \\ ${ }^{3}$ Universitas Riau, Pekanbaru, Indonesia \\ Correspondence: Arumega Zarefar, Universitas Riau, Pekanbaru, Indonesia.
}

Received: April 20, 2019

Accepted: May 7, 2019

Online Published: May 19, 2019

doi:10.5430/ijfr.v10n3p77

URL: https://doi.org/10.5430/ijfr.v10n3p77

\begin{abstract}
This study examined auditors' ethical judgments using two theoretical perspectives; (1) Moral intensity constructs of Jones' (1991) Model and (2) Forsyth's (1980) framework of individual ethical orientation. The importance of the moral issues and how they affected the auditors' ethical judgments together with the influence of individual's ethical orientation and the client importance is discussed. A research instrument consisted of two scenarios with different level of moral intensity issues and utilized a 12-item of moral intensity measurement and a Forsyth's (1980) scale to measure ethical orientation along two dimensions, idealism and relativism. The client importance is manipulated in this between-subjects study. The results of 152 auditors' found that the effects of the moral intensity construct and the client importance on auditors' ethical judgments is different based on the issues intensity level of the scenarios. Whereas, both dimensions of the individual ethical orientation (idealism and relativism) are found significant in both of the scenarios tested. The limitations of the study and recommendation for future studies are also discussed.
\end{abstract}

Keywords: moral intensity, ethical orientation, client importance, auditor's ethical judgments

\section{Introduction}

The failure of some large companies in the west (Enron, WorldCom and Lehman Brothers) as well as in Malaysia (Perwaja Steel Berhad, Transmile Group Berhad, PKFZ Berhad) without auditors warning raised serious questions concerning the ethicality of the auditors. In performing their duties, auditors are often faced with situation involving financial integrity thus, their ethical considerations are often challenged. Their ethical judgments have to meet up with both ethical obligation (between auditors \& public) and contractual obligation (between auditors \& management), and this is where the auditors' conflict will arise (Westra, 1986). The conflicts of interest among the client firm, the public, the audit firm and the auditing profession provide the bases for many of the potential ethical issues that auditors must resolve within their profession. In understanding the ethical judgments of an individual, Jones (1991) argued that one should recognized and investigated the specific characteristics of moral issues (moral intensity) together with other personal and situational factors. According to Jones (1991), the moral intensity of the issue captures the heightened feelings and emotions of a particular ethical conflict and there are certain properties within an ethical issue that make the issue more salient and vivid to the decision-maker.

The ethical judgments also tends to vary according to personal ethical orientation which comprised of two underlying components i.e. idealism and relativism (Forsyth, 1980). Current theoretical views maintain that an individual's personal ethical orientation influences ethical judgments of professionals including accountants (e.g. Johari et al., 2017; Greenfield et al., 2008; Henle et al., 2005; Achilles, 2006). The differences in ethical orientation can result in disagreements about what is ethical per se, about the situations to which a person should be sensitive and about the ethical judgments made. Besides that, research on ethics also suggests that increased pressures (Shafer et al., 1999) could be associated with unethical decision-making since it impaired the auditors' judgments. The client importance is viewed as pressure-inducing which can threaten auditors' judgments and could lead to unethical behavior (Riaz \& Riaz 2018; DeZoort et al., 2006; Jones et al., 2003). Noting the importance of moral intensity construct, ethical orientation dimensions and client importance in shaping the auditors' ethical judgments, this current study intends to provide further evidence by investigating together these three variables on auditors' ethical 
judgments. In particular, the objective of this study is to identify the role of moral intensity components in determining the auditors' ethical judgments and how the differences in ethical orientation could influence the auditors' ethical judgments. At the same time, this study will also examine the effect of the client importance on the auditors' ethical judgments respecting to the different levels of moral intensity issues.

\section{Literature Review and Hypothesis Development}

\subsection{Ethical Judgment}

According to Hunt and Vitell (1986), the ethical judgments is the stage where a person has recognized the ethical issues and considers alternatives that best solve the problem to attain the most beneficial outcome. The judgments are formed after taking all the considerations of what are morally right and wrong in the context of acceptable standards.

\subsection{Moral Intensity}

The moral intensity construct in Jones' (1991) issue-contingent model refers to "the extent or degree of issue-related moral imperative in a situation". The core concept of this model, moral intensity, claims that one's perception, evaluation and response to a moral issue stem from characteristics of the issue itself. Jones argued that the moral intensity of an issue would influence the recognition of an issue as an ethical problem and the subsequent behavior in which the decision maker engages. The moral intensity is a multidimensional construct consisting of six issue contingencies i.e. magnitude of consequences, social consensus, temporal immediacy, proximity, probability of effect and concentration of effect (Jones, 1991). Previous studies have found some significant effect of the moral intensity components on the ethical judgments made by auditors (Johari et al., 2016; Cohen \& Bennie, 2006) and accounting students (Leitsch, 2006; Sweeney \& Costello, 2009; Rismayadi \& Maemunah 2018). Similar to the researchers done in business/marketing area, the components of magnitude of consequences and social consensus are proven as the two most significant components that could influence the auditors' ethical judgments followed by the component of probability of effect. In addition, research using the moral intensity construct in auditing is still developing (Cohen and Bennie, 2006). Therefore, based on the preceding discussion, the following hypotheses will be investigated:

H1: The components of moral intensity will be positively associated with auditor's ethical judgments.

\subsection{Ethical Orientation}

Personal ethical orientation conceptualized by Forsyth (1980), is based on the philosophical theories of deontology, teleology and ethical skepticism. In 1980, Forsyth developed the Ethics Position Questionnaire (EPQ) to identify an individual's personal ethical orientation. Forsyth (1980) proposes that differences in individual's personal ethical orientation can be parsimoniously described by the degree to which they are idealistic or relativistic. Idealism referred to an individual believes that ethically correct actions will consistently produce desirable outcomes whereas relativism represents an individual's concern for a universal set of rules or standards (Forsyth, 1980). Empirically, studies using the EPQ help to explain a variety of decisions that individuals make in organizations (e.g. Johari et al., 2017; Kaditti \& Asri, 2017; Henle et al., 2005; Marques \& Pireira, 2009). In general, the research indicates that relativistic individuals judge ethically uncertain actions more leniently whereas an idealistic individual are harsher on any unethical actions. Fernando \& Chowdhury (2010) results revealed that spiritual well-being is strongly correlated only with the idealism orientation. Henle et al., (2005) found that employees with higher degrees of relativism than idealism were more likely to engage in unethical behaviors toward the organization. In respect to the accounting ethics, the EPQ instrument has been used in prior studies (e.g. Marques \& Pereira, 2009; Greenfield et al., 2008). Greenfield et al. (2008) found a significant relationship between tax practitioners' ethical orientation and ethical decision-making. Marques \& Pereira (2009) have provided the dissimilar results to previous researches. Their results indicated that older respondents were significantly more relativistic than younger one and those respondents' ethical judgments did not differ significantly based on their ethical orientation, neither idealism nor relativism. Therefore, based on the preceding discussion, the following hypotheses will be tested:

H2 (a): Idealistic ethical orientation has a positive relationship with auditors' ethical judgments.

H2 (b): Relativistic ethical orientation has a negative relationship with auditors' ethical judgments.

\subsection{Client Importance}

Client importance is extensively used in auditor independence, earnings management and audit quality studies which requires auditors to make certain judgments in exercising their duties. According to DeAngelo (1981), the client importance may influence the auditors' incentives to compromise their independence. From the literature, studies that have directly examining the influence of client importance have offered mixed results (e.g. Barrainkua \& 
Espinosa-Pike, 2018: Nelson et al., 2002; Moreno \& Bhattacharjee, 2003). Farmer et al., (1987) and Nelson et al., (2002) results supported the negative impact of client importance on auditors' judgments. Chi et al., (2004) in their study (at the audit-partner level) also found that a higher level of client importance reduces audit quality. Contrary results to Chi et al., (2004) were found in a study done by Moreno \& Bhattacharjee (2003). Their study revealed that the higher rank auditors (managers and partners) did not judged the obsolescence risk to be lower when provided with information on additional client business opportunities. Li (2010) added to the literature by providing evidence on the positive association between the client importance and auditors' judgments in issuing going-concern opinions. There are also studies which found no association between client importance and auditors' judgments (e.g. Chung, 2003; Hunt \& Lulseged, 2007; Rosli \& Siong 2018). Therefore, based on the preceding discussion, the following hypotheses will be investigated:

H3: Client importance has a positive relationship with auditors' ethical judgments.

\section{Methodology}

\subsection{Sample and Data Collection}

The sampling frame was based on the approved audit firms in Selangor and Wilayah Persekutuan Kuala Lumpur totaling 198 firms as published on the CPA Malaysia's website www. .micpa.com.my/resources/approved-training-employers/approved-accounting-firm/. The samples were drawn from 132 audit firms and based on simple random sampling (Hair et. al., 2010). Each of the audit firms received 5 survey booklets, in total, 660 survey booklets were distributed and 156 responded with the response rate of $23.6 \%$. Out of this figure, 4 respondents were identified as outliers and were dropped from the sample. As a result, a total number of questionnaires analyzed were 152. Attached to the booklet were a set of self-addressed, stamped envelope, as well as a cover letter stating that the study aimed to examine the auditors' ethical judgment and assuring anonymity and confidentiality.

\subsection{Variable and Measurement}

This study uses ethical judgments as dependent variable, ethical orientation, characteristics of the moral issues (moral intensity) and client importance as independent variables. The ethical judgments were measured directly by asking the respondents to respond to their level of agreement with the action statement in the two scenarios (underreporting of time and non-compliance). Both scenarios represent ethical dilemmas that auditors encounter in practice also possess varying degrees of moral intensity. The components of moral intensity were measured based on Jones' (1991) work and adapted from previous research (Singhapakdi et al., 1996; McMahon \& Harvey, 2006). The ethical orientation is measured by using instrument developed by Forsyth (1980). A 20-question consisted of 10 questions each on idealism (IEO) and relativism (REO) were used to identify the respondent's ethical orientation. Responses to the above measurement was made on seven-point scale ( $1=$ strongly disagree; $7=$ strongly agree $)$. Client importance is manipulated as a between-subject variable and is measured as a dichotomous variable.

\section{Results}

\subsection{Demography of Participants}

Table 1 presents the summary of respondents' demographic information. In respect to gender, there are 62 males (41 percent) and 90 females (59 percent). The age of the respondents ranged from 21 to 52 years with a mean value of 26.58 years $(S D=4.7)$. Majority of the respondents were the degree holder ( 66 percent) followed by the professional qualification (30 percent) and the rest of 4 percent are the diploma holder.

Table 1. Demography of participants

\begin{tabular}{|c|c|c|c|c|c|}
\hline & Frequency & Percent & & Frequency & Percent \\
\hline Item & $(\mathrm{N}=152)$ & & Item & $(\mathrm{N}=152)$ & \\
\hline Gender: & & & Job Position: & & \\
\hline Male & 62 & 41 & Audit Assistant & 67 & 44 \\
\hline \multirow[t]{3}{*}{ Female } & 90 & 59 & Audit Senior & 41 & 27 \\
\hline & & & Audit Manager & 21 & 14 \\
\hline & & & Partner & 29 & 15 \\
\hline
\end{tabular}




\begin{tabular}{llllll}
\hline Race: & & & Audit Firm Category: & \\
Malay & 73 & 48 & Big 4 & 25 & 16 \\
Chinese & 56 & 37 & Medium & 65 & 43 \\
Indian & 23 & 15 & Small & 62 & 41 \\
\hline Qualification: & & & Age: & & \\
Diploma & 6 & 4 & Mean (Std Deviation) & $26.58(4.7)$ & \\
Degree & 100 & 66 & & & \\
Professional & 46 & 30 & & & \\
& & & & & \\
\hline
\end{tabular}

The sample of respondents included audit assistants (44 percent), audit senior (27 percent), audit manager (14 percent) and partner (15 percent). Most of them (43 percent) are currently being attached to a medium audit firm category. Therefore, another 16 percent and 41 percent of the respondents are from a big 4 and small audit firm category, respectively.

\subsection{Descriptive Statistics}

\subsubsection{Means for Measured Variables}

Table 2(a) presents a preliminary analysis of the responses for auditors' ethical judgments and the six components of moral intensity, for each of the scenarios. In this study, the level of score was analyzed into three categories, namely high $(>66.67 \%)$, moderate $(33.33 \%-66.66 \%)$ and low $(<33.32 \%)$. The overall moral intensity mean scores for Scenario $2($ mean $=4.70)$ is higher than Scenario $1($ mean $=4.35)$ which indicates a higher agreement among the respondents that Scenario 2 as a situation with a higher level of intensity $(67.14 \%)$ as compared to the Scenario 1 (moderate level of intensity i.e. 62.14\%).

Table 2(a). Means for ethical judgments and moral intensity

\begin{tabular}{|c|c|c|c|c|c|}
\hline & \multicolumn{2}{|c|}{ Scenario $1^{*}$} & \multicolumn{2}{|c|}{ Scenario $2 *$} & \multirow[t]{2}{*}{ t-test } \\
\hline & Mean & $\mathrm{SD}^{* *}$ & Mean & $\mathrm{SD}^{* *}$ & \\
\hline Ethical Judgments & 4.62 & 1.74 & 5.11 & 1.41 & $3.56^{\mathrm{b}}$ \\
\hline \multicolumn{6}{|l|}{ Moral Intensity Components: } \\
\hline Magnitude of consequences (MOC) & 4.68 & 1.63 & 5.06 & 1.57 & $2.57^{\mathrm{a}}$ \\
\hline Social consensus (SC) & 4.60 & 1.55 & 5.18 & 1.72 & $3.66^{\mathrm{b}}$ \\
\hline Probability of effect (POE) & 3.83 & 1.29 & 4.34 & 1.64 & $3.50^{\mathrm{b}}$ \\
\hline Temporal immediacy (TI) & 4.26 & 1.55 & 4.25 & 1.66 & 0.07 \\
\hline Proximity $(\mathrm{Px})$ & 4.85 & 1.17 & 4.91 & 1.20 & 0.61 \\
\hline Concentration of effect (COE) & 3.90 & 1.39 & 4.48 & 1.62 & $3.99^{\mathrm{b}}$ \\
\hline
\end{tabular}

* Scenario 1: Underreporting of time; Scenario 2: Non-compliance ** SD = Standard Deviation

${ }^{\mathrm{a}} \mathrm{p}<0.05$ (2-tailed), ${ }^{\mathrm{b}} \mathrm{p}<0.10$ (2-tailed)

In Scenario 1, two components of moral intensity i.e. proximity (70\%) and magnitude of consequences (67\%) were identified as the components with high intensity level while in Scenario 2, the high intensity level components comprised of social consensus (74\%), magnitude of consequences (72.3\%) and proximity (70\%). Other components showed a moderate level of intensity for both scenarios.

Table 2(b) provides the mean and standard deviation values for ethical ideology components. Overall, the mean value of IEO (mean value $=5.5$, std. dev. $=0.8$ ) is 0.9 higher than the mean value of $\mathrm{REO}$ (mean value $=4.6$, std. dev. $=0.7$ ). Therefore, on average, all the respondents have higher levels of IEO compared to REO. 
Table 2(b). Means for ethical orientation

\begin{tabular}{lcc}
\hline & Mean & SD $^{* *}$ \\
\hline $\begin{array}{l}\text { Ethical Orientation Components: } \\
\text { Idealism }\end{array}$ & 5.53 & 0.78 \\
\hline Relativism & 4.61 & 0.72 \\
\hline
\end{tabular}

\subsection{Goodness of Data}

An exploratory factor analysis using varimax rotations was performed to understand the structure of correlations among the two constructs of moral intensity and ethical orientation in each scenario. All the items should have the factor loadings above 0.50 which indicates that the data is practically significant (Hair et al., 2010; Rotova,2018). In particular, the higher the factor loading, the more likely the items meet each factor of ethical orientation. The items were then extended for reliability analysis in order to determine the measure of internal consistency of measuring items under each construct. The reliability coefficient i.e. Cronbach's alpha value should exceed the minimum requirement of .60 (Hair et al., 2010).

\subsubsection{Moral Intensity}

Table 3 shows the Kaiser-Meyer-Olkin coefficient for these dataset is 0.56 for Scenario 1 and 0.55 for Scenario 2, indicating that the data could be used to proceed with the exploratory factor analysis (Hair et al., 2010). In addition, the Bartlett test of Sphericity for Scenario 1 (Chi-Square $=1409.67$, d.f. $=66, p<0.01$ ) and Scenario 2 (Chi-Square $=1978.08$, d.f. $=66, \mathrm{p}<0.01)$ are statistically significant. The results of the factor analysis for both scenarios identified six identical factors for moral intensity with an eigenvalue greater than 1 , which account for 91.46 percent (Scenario 1) and 95.1 percent (Scenario 2) of the total variance. Hence, these results provided evidence for the six dimensions of moral intensity, thus confirm Jones (1991) theory.

Table 3. Factor analysis

\begin{tabular}{|c|c|c|c|c|c|c|c|c|c|c|c|c|c|}
\hline & & Scen & o $1 *$ & & & & & Scen & io $2 *$ & & & & \\
\hline & & 1 & 2 & 3 & 4 & 5 & 6 & 1 & 2 & 3 & 4 & 5 & 6 \\
\hline MOC & Item 1 & .932 & & & & & & .949 & & & & & \\
\hline & Item 2 & .938 & & & & & & .969 & & & & & \\
\hline $\mathrm{SC}$ & Item 1 & & .963 & & & & & & .964 & & & & \\
\hline & Item 2 & & .963 & & & & & & .967 & & & & \\
\hline POE & Item 1 & & & .923 & & & & & & .953 & & & \\
\hline & Item 2 & & & .959 & & & & & & .967 & & & \\
\hline TI & Item 1 & & & & .934 & & & & & & .957 & & \\
\hline & Item 2 & & & & .947 & & & & & & .965 & & \\
\hline Px & Item 1 & & & & & .909 & & & & & & .945 & \\
\hline & Item 2 & & & & & .899 & & & & & & .946 & \\
\hline $\mathrm{COE}$ & Item 1 & & & & & & .910 & & & & & & .976 \\
\hline & Item 2 & & & & & & .946 & & & & & & .976 \\
\hline
\end{tabular}

Note: * Scenario 1: Underreporting time; Scenario 2: Non-compliance

MOC $=$ Magnitude of consequences, $\mathrm{SC}=$ Social consensus, $\mathrm{POE}=$ Probability of effect, $\mathrm{TI}=$ Temporal immediacy, $\mathrm{Px}=$ Proximity, $\mathrm{COE}=$ Concentration of effect)

The moral intensity scale reliability analysis for each scenario (Table 4) demonstrated an acceptable individual alpha coefficient as suggested by Hair et al., (2010). Scenario 1 provided a Cronbach's alpha reliability coefficient of 0.653 (standardized item alpha of 0.657 ) and Scenario 2 with a Cronbach's alpha reliability coefficient of 0.703 
(standardized item alpha of 0.703). In addition, the moral intensity components for these two scenarios were summed to yield a global alpha score of moral intensity which yielded a score of 0.763 with a standardized item alpha of 0.771. This indicates that the components of moral intensity in both scenarios have sufficient internal consistency.

Table 4. Reliability test

\begin{tabular}{llll}
\hline Reliability coefficients & Scenario $1^{*}$ & $\begin{array}{l}\text { Scenario } \\
2^{*}\end{array}$ & $\begin{array}{l}\text { Combined } \\
\text { scenarios }\end{array}$ \\
\hline Cronbach's Alpha & .653 & .703 & .763 \\
Standardized Item Alpha & .657 & .703 & .771 \\
N of items & 12 & 12 & 24 \\
\hline
\end{tabular}

Note: *Scenario 1: Underreporting of time; Scenario 2: Non-compliance

\subsubsection{Ethical Orientation}

Table 5 shows the factor loadings for each IEO and REO with the eigenvalues more than 1.0, which account for 42.60 percent and 32.62 percent, respectively of the total variance in the data. The Kaiser-Meyer-Olkin coefficient for these dataset is 0.765 for IEO and 0.683 for REO. The Bartlett test of Sphericity for IEO (Chi-Square $=329.17$, d.f. $=21, \mathrm{p}<0.01)$ and REO (Chi-Square $=248.50$, d.f. $=28, \mathrm{p}<0.01)$ are statistically significant. These results provide evidence for the two dimensions of ethical orientation, i.e. idealism and relativism with seven and eight items, respectively. Table 6 shows the values of Cronbach's alpha coefficient for IEO and REO which also indicate that each dimension of IEO and REO has sufficient internal consistency.

Table 5. Factor analysis

\begin{tabular}{llll}
\hline Item & Factor Loadings & Item & Factor Loadings \\
\hline IEO 1 & .555 & REO 1 & .534 \\
IEO 4 & .742 & REO 3 & .523 \\
IEO 5 & .712 & REO 4 & .636 \\
IEO 6 & .825 & REO 5 & .641 \\
IEO 8 & .603 & REO 6 & .571 \\
IEO 9 & .516 & REO 8 & .553 \\
IEO 10 & .573 & REO 9 & .558 \\
& & REO 10 & .558 \\
\hline
\end{tabular}

Note: IEO = Idealism Ethical Orientation, REO = Relativism Ethical Orientation

Table 6. Reliability test

\begin{tabular}{lll}
\hline Reliability coefficients & IEO $^{*}$ & REO* \\
\hline Cronbach's Alpha & .76 & .70 \\
Standardized Item Alpha & .77 & .70 \\
N of items & 7 & 8 \\
\hline
\end{tabular}

(Note: $*$ IEO = Idealism Ethical Orientation, $*$ REO = Relativism Ethical Orientation)

\subsection{Correlation Analysis}

Table 7 describes the analysis of pearson correlation between variables for each of the scenarios. In Scenario 1, there are three components of moral intensity (i.e. social consensus, proximity and concentration of effect) which 
significantly correlates to the auditors' ethical judgments. Besides, more moral intensity components (i.e social consensus, proximity, magnitude of consequences and temporal immediacy) are significantly related in Scenario 2.

Table 7. Correlation analysis

\begin{tabular}{llllllllll}
\hline & Ethical Judgments & MOC & SC & POE & TI & PX & COE & IEO & REO \\
\hline Scenario $1^{*}:$ & \multicolumn{1}{l}{ MOC } & -.038 & & & & & & & \\
\hline SC & $.167^{\mathrm{a}}$ & $-.140^{\mathrm{a}}$ & & & & & & \\
\hline POE & -.080 & $.154^{\mathrm{a}}$ & .036 & & & & & \\
\hline TI & .052 & $.185^{\mathrm{b}}$ & .014 & $.231^{\mathrm{b}}$ & & & & \\
\hline PX & $.182^{\mathrm{b}}$ & -.048 & .058 & $-.195^{\mathrm{b}}$ & .031 & & & \\
\hline COE & $.137^{\mathrm{a}}$ & $.243^{\mathrm{b}}$ & -.069 & $.267^{\mathrm{b}}$ & $.379^{\mathrm{b}}$ & .109 & & \\
\hline IEO & $.224^{\mathrm{b}}$ & -.017 & $.143^{\mathrm{a}}$ & -.045 & .012 & .065 & .008 & & \\
\hline REO & $-.202^{\mathrm{b}}$ & -.019 & -.014 & $.135^{\mathrm{a}}$ & $-.123^{\mathrm{a}}$ & $-.168^{\mathrm{b}}$ & $-.155^{\mathrm{a}}$ & .099 & \\
\hline Client type & .058 & -.006 & -.024 & -.108 & $.163^{\mathrm{a}}$ & .028 & .040 & $.125^{\mathrm{a}}$ & $-.130^{*}$ \\
\hline Scenario $2^{*}:$ & & & & & & & & & \\
\hline MOC & $-.132^{\mathrm{a}}$ & & & & & & & & \\
\hline SC & $.279^{\mathrm{b}}$ & .003 & & & & & & & \\
\hline POE & .015 & $.124^{\mathrm{a}}$ & $.245^{\mathrm{b}}$ & & & & & & \\
\hline TI & $.195^{\mathrm{b}}$ & $.136^{\mathrm{a}}$ & .118 & $.190^{\mathrm{b}}$ & & & & & \\
\hline PX & $.295^{\mathrm{b}}$ & $.120^{\mathrm{a}}$ & $.309^{\mathrm{b}}$ & $.198^{\mathrm{b}}$ & $.185^{\mathrm{b}}$ & & & & \\
\hline COE & -.012 & $.178^{\mathrm{b}}$ & .058 & .075 & $.188^{\mathrm{b}}$ & -.063 & & & \\
\hline IEO & $.212^{\mathrm{b}}$ & -.037 & $.156^{\mathrm{a}}$ & .082 & .053 & $.163^{\mathrm{a}}$ & .015 & & \\
\hline REO & $-.193^{\mathrm{b}}$ & -.025 & $-.163^{\mathrm{a}}$ & $-.134^{\mathrm{a}}$ & $-.139^{\mathrm{a}}$ & -.109 & .057 & .099 & \\
\hline Client type & $.186^{\mathrm{b}}$ & -.042 & -.006 & .023 & -.036 & .040 & .033 & $.125^{\mathrm{a}}$ & $-.130^{\mathrm{a}}$ \\
\hline
\end{tabular}

${ }^{\text {a }}$ Correlation is significant at the level 0.05 level (2-tailed)

${ }^{\mathrm{b}}$ Correlation is significant at the level 0.01 level (2-tailed)

Note: * Scenario 1: Underreporting of time; *Scenario 2: Non-compliance

MOC $=$ Magnitude of consequences, $\mathrm{SC}=$ Social consensus, $\mathrm{POE}=$ Probability of effect, $\quad \mathrm{TI}=$ Temporal immediacy, $\mathrm{Px}=$ Proximity, $\mathrm{COE}=$ Concentration of effect, $\mathrm{IEO}=$ Idealism Ethical Orientation, $\mathrm{REO}=$ Relativism Ethical Orientation

For the ethical orientation components, both idealism and relativism ethical orientation provide support for their expected direction to audit judgments performance. The results show that significantly, auditors who are more on idealism and relativism ethical ideology will positively and negatively affect their ethical judgments. The correlation between client importance and auditors' ethical judgments is significantly related in Scenario 2 but not in Scenario 1. Therefore, from the correlation analysis, it is identified that the moral intensity components and client importance are differently correlated to auditors' ethical judgments based on the scenario given. The most two dominant moral intensity components which constantly have a significant correlation to the auditors' ethical judgments were social consensus and proximity, followed by magnitude of consequences and temporal immediacy. On the other hand, the ethical orientation components are constantly correlated to the auditors' ethical judgments in both scenarios.

\subsection{Hypotheses Testing}

Since the moral intensity construct is issue-specific and thus scenario-specific, separate hierarchical regression analyses were run for each of the scenarios. Multicollinearity among the independent variables does not appear to be 
a problem as the range of the tolerance value and VIF (variance inflation factor) of the variables have not violated the multicollinearity assumption suggested by Pallant, (1997). The tolerance value for all the independent variables is between 0.757 and 0.944 , which is not less than .10. This value is also supported by the VIF value which lies between 1.064 and 1.321, which is well below the cut-off of 10. Results of the analyses appear in Table 8 .

In regard to the moral intensity construct, generally there were only two components of the moral intensity components (i.e. social consensus and proximity) significantly related to the auditors' ethical judgments in Scenario 1. Besides, in Scenario 2 more components (i.e social consensus, proximity, magnitude of consequences and temporal immediacy) were found significantly influences the auditors' ethical judgments. Social consensus and proximity appear to be the most two predictive components where they were positively significant related to the auditors' ethical judgments in Scenario $1(\mathrm{p}<.10)$ and Scenario $2(\mathrm{p}<.05)$. There was also a significant positive relationship between the components of magnitude of consequences, temporal immediacy and auditors' ethical judgments in the second scenario $(\mathrm{p}<.05)$. The direction of the significant relationship between auditors' ethical judgments and some of the respective moral intensity components indicates as issues became more intense, auditors will form more ethical judgments. Since not all of the moral intensity components influenced auditors' ethical judgments, these results provide partial support for $\mathrm{H} 1$.

Table 8. Hierarchical regression analyses

\begin{tabular}{|c|c|c|c|c|}
\hline \multirow[b]{3}{*}{ Independent Variables } & \multicolumn{4}{|c|}{ Dependent Variable: Auditors' Ethical Judgments } \\
\hline & \multicolumn{2}{|l|}{ Scenario $1^{*}$} & \multicolumn{2}{|l|}{ Scenario $2^{*}$} \\
\hline & Coefficients & Standard error & Coefficients & Standard error \\
\hline Constant & 2.522 & 1.394 & 3.399 & .993 \\
\hline IEO & $.469^{\mathrm{a}}$ & .158 & $.252^{\mathrm{a}}$ & .121 \\
\hline REO & $-.429^{\mathrm{a}}$ & .177 & $-.262^{\mathrm{a}}$ & .134 \\
\hline MOC & -.038 & .077 & $.139^{\mathrm{a}}$ & .060 \\
\hline $\mathrm{SC}$ & $.152^{\mathrm{b}}$ & .079 & $.149^{\mathrm{a}}$ & .058 \\
\hline POE & -.081 & .103 & -.098 & .059 \\
\hline TI & -.008 & .086 & $.134^{\mathrm{a}}$ & .058 \\
\hline $\mathrm{PX}$ & $.167^{\mathrm{b}}$ & .099 & $.242^{\mathrm{a}}$ & .083 \\
\hline $\mathrm{COE}$ & .154 & .107 & $\begin{array}{l}.002 \\
\end{array}$ & .059 \\
\hline $\mathrm{CI}$ & -.006 & .249 & $.410^{\mathrm{a}}$ & .186 \\
\hline$\overline{\mathrm{R}^{2}}$ & .148 & & .244 & \\
\hline
\end{tabular}

Note: *Scenario 1: Underreporting time; *Scenario 2: Non-compliance

MOC $=$ Magnitude of consequences, $\mathrm{SC}=$ Social consensus, $\mathrm{POE}=$ Probability of effect, $\quad \mathrm{TI}=$ Temporal immediacy, $\mathrm{Px}=$ Proximity, $\mathrm{COE}=$ Concentration of effect, $\mathrm{IEO}=$ Idealism Ethical Orientation, $\mathrm{REO}=$ Relativism Ethical Orientation, $\mathrm{CI}=$ Client Importance

Table 8 also revealed the relationship between the ethical orientation construct and auditors' ethical judgments. Both components of ethical orientation i.e idealism and relativism, were found significantly predicted the auditors' ethical judgments in Scenario 1 and Scenario 2. The positive direction of the relationship between auditors' ethical judgments and idealism indicates that the more idealistic auditors tend to be more likely to follow an ethical action thus avoiding the questionable actions expressed in both of the scenarios. In contrast, the negative direction of the relationship between auditors' ethical judgments and relativism indicates that the more relativism auditors tend to be more likely to follow the questionable actions expressed in both of the scenarios. Therefore, $\mathrm{H} 2$ (a) and $\mathrm{H} 2$ (b) were strongly supported. For client importance, the result shows that it was positively significant to auditors' ethical judgments in Scenario 2 but not in Scenario 1. Thus, H3 was partially supported by the data. 


\section{Discussion}

\subsection{Discussion of Findings}

This current study was intended to provide a better understanding regarding the effects of moral intensity construct, ethical orientation components and client importance on ethical judgments among the auditors. The auditors' perception for each of the moral intensity components appeared to vary between each scenarios and being influenced by the ethical issue presented to them. The analysis revealed that auditors have identified the different level of moral intensity issues among the two scenarios and advocated different predictive power of the moral intensity components (Johari et al., 2017; Yenny \& Nurkholis, 2017; Salim \& Hariandja 2018). The results indicated that the auditors' perception for each of the moral intensity components appeared to vary between each scenario and was consistent with previous results done by Sweeney \& Costello (2009) and Leitsch (2006). The component of social consensus revealed as the most important component of moral intensity and significantly impacted the auditors' ethical judgments in both of the scenarios. This finding is contrary to previous studies (e.g. Singhapakdi et al., 1996; Sweeney \& Costello, 2009). Previously, in a study done on professionals, the magnitude of consequences appeared to be the most important components compared to other components of moral intensity. The importance of social consensus indicates that auditors' perceptions of society's attitudes to issues influence their decisions. This indication is consistent with lower levels of cognitive moral development (Kohlberg, 1969) and Barnett (2001) also pointed out that respondents around the age of 20 are expected that their beliefs about societal opinion would be a very important influence.

Another moral intensity component which significantly correlated with the auditors' ethical judgments in both scenarios is proximity. The results revealed that proximity has the strongest relationship throughout the three stages of auditors' ethical decision-making process which is inconsistent with previous studies (e.g. Sweeney \& Costello, 2009; Singhapakdi et al.; 1996). Jones (1991) claims that people care more about other people who are close to them (socially, culturally, psychologically or physically) than they do for people who are distant. Based on this assertion, Malaysian auditors seem to place a higher consideration towards the proximity components as compared to other components of moral intensity. This might be due to the notion that Malaysian people are more considerate in making judgment when the consequences will impact the people who are close to them.

In regard to the personal ethical orientations both components i.e. idealism and relativism were found significantly influenced the auditors' ethical judgments in Scenario 1 and Scenario 2. The auditors' level of idealism was found higher than the level of relativism. This indicates that the auditors are more concern towards the human welfare in making up their ethical judgments. They tend to support the ethical correct actions and will not compromise with any actions which could give harms to others. This finding supported previous studies' results for example, Viruli, Silva \& Opatha (2018); Johari et al., (2017) and Greenfield et al., (2008). Finally, concerning the effect of client importance on auditors' ethical judgments, the results do support the previous studies on the positive effect of client importance on audit judgments (e.g. Moreno \& Bhattacharjee, 2003 and Li, 2010). However, the significant positive relationship between these two variables was only found in Scenario 2 . This could be explained by the differences of the ethical issues which have a different level of intensity embedded in scenarios. Scenario 1 was perceived as having less intense of ethical issues compared to Scenario 2. The low level of ethical intense in Scenario 1 has led the auditors to not perceive the importance of the moral intensity components in the scenario. Therefore, although the auditors do recognized the negative impact of client importance on their ethical judgments but it is not strong enough to jeopardize their ethical judgments.

In conclusion, this current study extends the previous work on moral intensity by examining the influence of moral intensity together with personal ethical orientation and client importance on the auditors' ethical judgments. In general, the findings add to the existing business ethics literature. Particularly, they extend the existing understanding of the influence of moral intensity components on the ethical judgments within the auditing profession. These findings can be used to enhance training programs in shaping the ethical values among the auditors in order to reinstall the public confidence towards the profession.

\subsection{Study Limitations and Future Research}

There are several limitations that should also be noted. First, respondents of this current study were given two ethical scenarios which might limit the respondents' perception towards the differences of moral intensity level embedded in the scenarios. The second limitation is that moral intensity was narrowly defined within the context of each scenario. These components may have been more or less intense depending upon the issue without the researcher detecting these differences. Future research should attempt to replicate these findings in other samples of accounting profession to ensure their generalizability. 


\section{References}

Achilles, W. W. (2006). An experimental analysis of the impact of goal orientation, ethical orientation and personality traits on managers and accountant's ability's to recognise misappropriation of assets. Doctoral Dissertation, Virginia Commonwealth University. Retrieved 26 October 2008, from htpp://www.proquest.umi.com

Barrainkua, I., \& Espinosa-Pike, M. (2018). The influence of auditors' professionalism on ethical judgement: Differences among practitioners and postgraduate students. Revista de Contabilidad - Spanish Accounting Review, 2l(2), 176-187. https://doi.org/10.1016/j.rcsar.2017.07.001

Chi, W., Huang, H., \& Liao, Y. (2004). The effect of auditor tenure and client importance on discretionary accruals - evidence from audit-partner based data in Taiwan.

Chung, H., \& Kallapur, S. (2003). Client importance, non-audit services, and abnormal accruals. The Accounting Review, 78(4), 931-55. https://doi.org/10.2308/accr.2003.78.4.931

Cohen, J. R., \& Bennie-Martinov, N. (2006). The Applicability of a Contingent Factors Model to Accounting Ethics Research. Journal of Business Ethics, 68, 1-18. https://doi.org/10.1007/s10551-006-9036-2

DeAngelo, L. (1981). Auditor size and audit quality. Journal of Accounting and Economics, 3, 183-99. https://doi.org/10.1016/0165-4101(81)90002-1

DeZoort, T., Harrison, P., \& Taylor, M. (2006). Accountability and auditors materiality judgments: the effects of differential pressure strength on conservatism, variability, and effort. Accounting, Organizations and Society, 31(4/5), 373-90. https://doi.org/10.1016/j.aos.2005.09.001

Farmer, T., Rittenberg, L., \& Trompeter, G. (1987). An investigation of the impact of economic and organization factors in auditor independence. Auditing: A Journal of Practice and Theory, 7(1), 1-14.

Fernando, M., \& Chowdhury, R. M. M. I. (2010). The relationship between spiritual well-being and ethical orientations in decision making: An empirical study with business executives in Australia. Journal of Business Ethics, 1-15. https://doi.org/10.1007/s10551-009-0355-y

Forsyth, D. R. (1980, July). A taxonomy of ethical ideologies. Journal of Personality and Social Psychology, 39 , 175-184. https://doi.org/10.1037//0022-3514.39.1.175

Greenfield, A. J., Norman, C., \& Wier, B. (2008). The effect of ethical orientation and professional commitment on earnings management behavior. Journal of Business Ethics, 83, 419-434. https://doi.org/10.1007/s10551-007-9629-4

Hair, J. F. Jr, Black, W. C., Babin, J. B., Anderson, R. E., \& Tatham, R. L. (2010). Multivariate DataAnalysis (7th ed.). Pearson Prentice-Hall, Upper Saddle River, NJ.

Henle, C., Giacalone, R., \& Jurkiwicz, C. L. (2005). The rule of ethical ideology in the workplace deviance. Journal of Business Ethics, 56(1), 219-230. https://doi.org/10.1007/s10551-004-2779-8

Hunt, A. K., \& Lulseged, A. (2007). Client importance and non-Big 5 auditors' reporting decisions. Journal of Accounting and Public Policy, 26(2), 212-248. https://doi.org/10.1016/j.jaccpubpol.2007.02.001

Hunt, S. D., \& Vitell, S. J. (1986). A general theory of marketing ethics. Journal of Macromarketing, 6(1), 5-16. https://doi.org/10.1177/027614678600600103

Johari, R. J., Mohd-Sanusi, Z., \& Vincent, K. C. (2017). Effects of Auditors' Ethical Orientation and Self-Interest Independence Threat on the Mediating Role of Moral Intensity and Ethical Decision-Making Process. International Journal of Auditing, 21(1), 38-58. https://doi.org/10.1111/ijau.12080

Johari, R. J., Mohd-Sanusi, Z., Abdul Rahman, R., \& Omar, N. (2016). Ethical Issues Characteristics and Its Relevance to Auditors' Ethical Decision Making in Malaysia. Sustainability and Management: An International Perspective, 205-214. https://doi.org/10.4324/9781315611440-15

Jones, J., Massey, D. W., \& Thorne, L. (2003). Auditors' ethical reasoning: Insights from past research and implications for the future. Journal of Accounting Literature, 22, 45-103.

Jones, T. M. (1991). Ethical decision-making by individuals in organizations: An issue-contingent model. The Academy of Management Review, 16(2), 366-395. https://doi.org/10.5465/amr.1991.4278958

Kaditti, B. Y., \& Asri, M. (2017). Auditor Ethical Decision Making. Scientific Research Journal (SCIRJ), V(VI), $27-45$. 
Kohlberg, L. (1969). Stage and sequence: The cognitive-development approach to socialization. In D. Goslin (Ed.), Handbook of Socialization Theory and Research. IL: Rand McNally.

Leitsch, D. L. (2006). Using Dimensions of Moral Intensity to Predict Ethical Decision-making in Accounting. Accounting Education, 15(2), 135-149. https://doi.org/10.1080/06939280600609151

$\mathrm{Li}, \mathrm{C}$. (2010). Does client importance affect auditor independence at the office level? Empirical evidence from going-concern opinions. Contemporary Accounting Research, 26(1), 201-230. https://doi.org/10.1506/car.26.1.7

Marques, P. A., \& Pereira, J. A. (2009). Ethical ideology and ethical judgments in the Portuguese accounting profession. Journal of Business Ethics, 86, 227-242. https://doi.org/10.1007/s10551-008-9845-6

McMahon, J. M., \& Harvey, R. J. (2006). An analysis of the factor structure of Jones' moral intensity construct. Journal of Business Ethics, 64, 381-404. https://doi.org/10.1007/s10551-006-0006-5

Moreno, K., \& Bhattacharjee, S. (2003). The impact of pressure from potential client business opportunities on the judgments of auditors across professional ranks. Auditing: A Journal of Practice \& Theory, 22, 13-28. https://doi.org/10.2308/aud.2003.22.1.13

Nelson, M., Elliott, J., \& Tarpley, R. (2002). Evidence from auditors about managers' and auditors' earnings management decisions. The Accounting Review, 77, 175-203. https://doi.org/10.2308/accr.2002.77.s-1.175

Pallant, J. (2007). SPSS Survival Manual. Sydney, Ligare Book Printer.

Riaz, N., \& Riaz, S. (2018). Investment and Economic Growth: A Panel Data Analysis. Asian Development Policy Review, 6(1), 20-31. https://doi.org/10.18488/journal.107.2018.61.20.31

Rismayadi, B., \& Maemunah, M. (2018). Creative Economy to Increase Community Revenue Based on Tourism Object, Medalsari Village, Pangkalan District Karawang Regency. Journal of Accounting, Business and Finance Research, 3(1), 28-35. https://doi.org/10.20448/2002.31.28.35

Rosli, A., \& Siong, T. I. (2018). Determinants of Customers Satisfaction Towards Services Provided by Agencies in Urban Transformation Centre (UTC). International Journal of Economics, Business and Management Studies, 5(1), 9-15. https://doi.org/10.20448/802.51.9.15

Rotova, N. A. (2018). Development of Independence among Future Primary School Teachers by Applying Interactive Learning Methods. Journal of Education and e-Learning Research, 5(2), 118-121. https://doi.org/10.20448/journal.509.2018.52.118.121

Saad, S., Umer, I., \& Ahmed, F. (2018). An empirical evidence of over reaction hypothesis on Karachi Stock Exchange (KSE). Asian Economic and Financial Review, 8(4), 449-465. https://doi.org/10.18488/journal.aefr.2018.84.449.465

Salim, M. N., \& Hariandja, N. M. (2018). Factors affecting joint stock price index (CSPI) and the impact of foreign capital investment (PMA) Period 2009 to 2016. Humanities and Social Sciences Letters, 6(3), 93-105. https://doi.org/10.18488/journal.73.2018.63.93.105

Shafer, W. E., Morris, R. E., \& Ketchand, A. A. (1999). The effects of formal sanctions on auditor independence. Auditing: A Journal of Practice \& Theory, 18, 113-5.

Silva, V., Opatha, H. H. D. N. P., \& Aruna, S. G. (2018). Does Ethical Orientation of HRM Impact on Employee Ethical Attitude and Behavior? Evidence from Sri Lankan Commercial Banks. International Business Research, 11(1), 217-229. https://doi.org/10.5539/ibr.v11n1p217

Singhapakdi, A., Vitell, S. J., \& Kraft, K. L. (1996). Moral intensity and ethical decision-making of marketing professionals. Journal of Business Research, 36(3), 245-255. https://doi.org/10.1016/0148-2963(95)00155-7

Sweeney B., \& Costello F. (2009). Moral intensity and ethical decision-making: An empirical examination of undergraduate accounting and business students. Accounting Education, 18(1), 75-97. https://doi.org/10.1080/09639280802009454

Westra, L. S. (1986). Whose 'Loyal Agent'? Towards an Ethic of Accounting. Journal of Business Ethics, 5, 119-128. https://doi.org/10.1007/BF00382753

Yeney, W., \& Nurkholis (2017). Moral Intensity, Organizational Factors, and Ethical Decision Making: An Empirical Examination of Postgraduate Accounting and Business Students. Review of Integrative Business and Economics Research, 6(3), 155-178. 